\title{
ANALISIS KINERJA KEUANGAN PT. BANK ACEH SYARIAH DENGAN MENGGUNAKAN MODEL SHARIA CONFORMITY AND PROFITABILITY (SCnP) DAN CAMEL
}

\author{
Sri Jayusma ${ }^{1}$, Musfiari Haridhi ${ }^{* 2}$ \\ ${ }^{1,2}$ Program Studi Akuntansi Fakultas Ekonomi Universitas Syiah Kuala \\ e-mail: azri28jayusma@gmail.com ${ }^{1}$, mus_sav@ unsyiah.ac.id ${ }^{* 2}$ \\ * Corresponding Author
}

\begin{abstract}
The purpose of this study was to analyze the financial performance of PT. Bank Aceh Syariah by using Sharia Conformity and Profitability ( SCnP) and CAMEL models, and to see the difference in the level of financial performance of the both models. Type of this research is quantitative descriptive analysis. The object of this research is PT. Bank Aceh Syariah. The data used are monthly financial statement for 28 months obtained from the official website of the bank. The results of this study show that by using SCnP the performance of banks is spread into four different quadrant almost every month and in 2018 the bank was able to show an increase which is on average Upper Right Quadrant (URQ). As for using CAMEL model, it shows good performance at the ratio of CAR, RORA, BOPO and FDR. While at the ratio of NPM and ROA the bank has not been able to reach the established criteria.
\end{abstract}

Keywords: Financial Performance, SCnP , and CAMEL

\section{Pendahuluan}

Keberadaan usaha-usaha berbasis syariah pada saat ini menjadi bukti adanya pertumbuhan dan perkembangan perbankan syariah di Indonesia yang terdiri dari Bank Umum Syariah, Unit Usaha Syariah, dan Bank Pengkreditan Rakyat Syariah (Endah et al., 2015). Selain memiliki fungsi pada hal komersial sesuai dengan Undang-undang Nomor 7 Tahun 1992 tentang Perbankan, perbankan syariah juga memiliki amanah dalam menjalankan fungsi secara sosial dengan menerima zakat, infaq, sadaqah, dan wakaf serta juga memberikan pembiayaan dengan konsep sosial (qardh). Maka oleh sebab itu perbankan syariah memiliki dua fungsi yaitu, fungsi komersial guna untuk mencari keuntungan seperti perbankan konvensional dan fungsi sosial untuk membantu masyarakat yang tidak memiliki kemampuan secara keuangan demi ikut membantu mensejahterakan kehidupan mereka (Sutrisno, 2014).

Fungsi yang dimiliki perbankan syariah tentunya berbeda dengan fungsi yang dimiliki perbankan konvensional, begitu pula dengan kegiatan operasional keduanya. Umardani dan Muchlish (2016) dalam penelitiannya mengatakan pada bank konvensional, bunga digunakan sebagai alat untuk memperoleh pendapatan. Sementara pada bank syariah, prinsip bagi hasil digunakan dalam kegiatan operasional dan tidak ada pemberian bunga.

Perbedaan prinsip antara kedua jenis bank ini tentunya menjadi salah satu faktor dalam meningkatkan kinerja pada masing-masing bank. Kinerja suatu bank menjadi pertimbangan yang cukup penting bagi pihak yang memiliki kepentingan pada bank tersebut seperti investor, kreditur, nasabah, karyawan, pemerintah, dan masyarakat. Laporan keuangan yang teratur diterbitkan bank dapat menjadi salah satu cara untuk melihat kinerja bank tersebut (Umardani dan Muchlish, 2016). Menurut Fauzan (2011) kinerja keuangan pada masa lalu menjadi informasi penting yang kerap kali menjadi dasar guna memprediksi kinerja keuangan dimasa depan.

Pada tanggal 25 Mei 2015 secara resmi PT. Bank Aceh merubah sistem usahanya dari sistem konvensional menjadi sistem syariah berdasarkan hasil Rapat Umum Pemegang Saham Luar Biasa. Hal ini menjadi catatan baru dalam sejarah keberadaan PT. Bank Aceh yang saat ini sudah menjadi PT. Bank Aceh Syariah. Izin konversi pelaksanaan 
kegiatan secara syariah secara langsung diserahkan kepada Gubernur Aceh Zaini Abdullah oleh Kepala OJK Provinsi Aceh Ahmad Wijaya Putra sesuai dengan keputusan Dewan Komisioner Otoritas Jasa Keuangan Nomor KEP-44/D.03/2016 tanggal 1 September 2016 Tentang Pemberian Izin Perubahan Kegiatan Usaha Bank Umum Konvensional menjadi Bank Umum Syariah PT. Bank Aceh (www.bankaceh.co.id).

Perubahan status syariah ini juga menjadikan PT. Bank Aceh Syariah berhasil menaikkan 20,54\% jumlah aset yang mereka miliki pada tahun 2017 sebesar Rp.22,61 triliun dari tahun sebelumnya sebesar Rp.18,75 triliun. Secara garis besar, dapat kita simpulkan ini merupakan prestasi yang baik mengingat mereka belum lama melakukan konversi. Selain berhasil meningkatkan nilai aset-nya, setelah konversi PT. Bank Aceh Syariah juga berhasil meningkatkan pembiayaan, dana pihak ketiga bahkan laba mereka di tahun yang sama (www.bankaceh.co.id). Hal tersebut tersaji pada Tabel 1.1.

\section{Tabel 1.1}

Jumlah Aset, Pembiayaan, Dana Pihak Ketiga dan Laba Setelah Pajak PT. Bank Aceh Syariah Tahun 2013-2017

\begin{tabular}{|l|l|l|l|l|}
\hline Tahun & Aset & $\begin{array}{l}\text { Pembiayaa } \\
\text { n }\end{array}$ & $\begin{array}{l}\text { Dana } \\
\text { Pihak } \\
\text { Ketiga }\end{array}$ & $\begin{array}{l}\text { Laba Setelah } \\
\text { Pajak }\end{array}$ \\
\hline 2013 & Rp.15,25 T & Rp.10,198 T & Rp.11,749 T & Rp.371,275 M \\
\hline 2014 & Rp.16,385 T & Rp.11,113 T & Rp.12,030 T & Rp.397,572 M \\
\hline 2015 & Rp.18,590 T & Rp.11,893 T & Rp.14,151 T & Rp.423,238 M \\
\hline 2016 & Rp.18,759 T & Rp.12,206 T & Rp.14,429 T & Rp.348,408 M \\
\hline 2017 & Rp.22,612 T & Rp.12,846 T & Rp.18,499 T & Rp.433,577 M \\
\hline
\end{tabular}

Sumber: www.bankaceh.co.id

Pada Tabel 1.1 dapat dilihat bahwa aset, pembiayaan, dana pihak ketiga, serta laba PT. Bank Aceh Syariah terus meningkat disetiap tahunnya, kecuali laba pada tahun 2016 yang mengalami penurunan dari tahun sebelumnya sebesar Rp.74,830 M. Hal ini menjadi pencapaian yang baik bagi PT. Bank Aceh Syariah yang juga sampai saat ini masih menjadi satu-satunya bank milik pemerintah daerah yang memiliki status sebagai bank syariah. Secara otomatis hasil perubahan status Bank Aceh menjadi bank syariah menambah aset bank syariah di Indonesia sebesar 20 triliun rupiah, pada sisi lain menurunkan aset Bank Konvensional sebesar 20 triliun rupiah (Farlian dan Nuraidar, 2017).

Fenomena beralihnya sistem operasional PT. Bank Aceh Syariah dari yang sebelumnya masih menggunakan sistem konvensional menjadi sebuah prestasi dan peristiwa penting dalam sejarah perekonomian di Aceh dan khususnya dalam lembaga keuangan itu sendiri. Secara perlahan Aceh mulai menerapkan syariat Islam pada semua gerak kehidupan masyarakatnya dan tak terkecuali sektor ekonomi dan perbankan pun menjadi perhatian pemerintah dan masyarakatnya. Oleh karena PT. Bank Aceh Syariah sudah memutuskan untuk menjalankan kegiatan operasionalnya secara syariah, maka yang menjadi harapan masyarakat tentunya bank mampu meningkatkan pertumbuhan ekonomi dan kesejahteraan masyarakat dengan menjalankan kegiatan operasional bisnis sesuai dengan tujuan dan fungsinya. Untuk mencapai itu semua, bank harus mampu memastikan bahwa mereka sudah melakukan kinerja yang terbaik dalam kegiatan operasional bisnisnya sehingga pihak-pihak luar bank dan masyarakat umum dapat menilai apakah bank sudah menjalankan kegiatannya dengan baik atau tidak.

\section{Rumusan Masalah}

Rumusan masalah yang coba peneliti kembangkan pada penelitian ini adalah:

1) Bagaimana tingkat kesesuaian syariah PT. Bank Aceh Syariah yang diukur dengan model Sharia Conformity and Profitability (SCnP)?

2) Bagaimana tingkat kesehatan PT. Bank Aceh Syariah yang diukur dengan model CAMEL?

3) Apakah terdapat perbedaan pada hasil penelitian yang dihitung dengan model $\mathrm{SCnP}$ dan CAMEL?

\section{Tujuan Penelitian}

Sesuai dengan rumusan masalah yang telah dikemukakan, maka tujuan penelitian ini adalah:

1) Untuk mengetahui tingkat kesesuaian syariah PT. Bank Aceh Syariah yang diukur dengan model SCnP (Sharia Conformity and Profitability). 
2) Untuk mengetahui tingkat kesehatan PT. Bank Aceh Syariah yang diukur dengan model CAMEL.

3) Untuk melihat perbedaan hasil penelitian yang dilakukan dengan model SCnP dan model CAMEL.

\section{Manfaat Penelitian \\ Manfaat Praktis}

Secara praktis, penelitian ini diharapkan dapat bermanfaat untuk:

1) Nasabah yang ingin melakukan ataupun yang sudah menggunakan produk-produk dan jasa-jasa serta yang ingin melihat kinerja pada aspek keuangan dari PT. Bank Aceh Syariah.

2) Para investor yang akan melakukan ataupun yang sudah melakukan investasi dan ingin melihat kinerja pada aspek keuangan dari PT. Bank Aceh Syariah.

3) Bagi PT. Bank Aceh Syariah, penelitian ini diharapkan dapat menjadi masukan, pertimbangan, dan referensi dalam melihat serta menilai aspek finansial dari aktifitas yang telah dilakukan.

\section{Manfaat Akademis}

1) Bagi kalangan akademisi, penelitian ini diharapkan dapat dijadikan referensi pada penelitian selanjutnya.

2) Bagi peneliti, penelitian ini diharapkan mampu memperkaya ilmu dan wawasan dari permasalahan yang diteliti.

\section{Kajian Pustaka dan Kerangka Pemikiran Perbankan Syariah \\ Defenisi Perbankan Syariah}

Bank merupakan lembaga keuangan yang memiliki banyak fungsi, diantaranya sebagai lembaga perantara antara pemilik uang dengan orang atau lembaga yang memerlukan uang. Para ahli pada umumnya sepakat bahwa bank merupakan lembaga keuangan yang mempunyai fungsi utama yaitu menerima simpanan giro, tabungan dan deposito serta tempat untuk meminjamkan uang (Nurdin, 2010:22).

\section{Produk Perbankan Syariah}

Pada praktiknya bank konvensional menawarkan berbagai macam produk keuangan kepada nasabahnya, demikian juga dengan bank syariah yang menawarkan produk-produk perbankan kepada nasabahnya. Perbedaannya hanyalah terletak pada penentuan harga baik terhadap harga jual maupun harga beli. Berikut adalah jenis-jenis produk bank syariah yang ditawarkan yaitu (Yaya,2016):
1) Murabahah
2) Mudharabah
3) Musyarakah
4) Salam
5) Istishna'
6) Ijarah

\section{Kinerja Keuangan}

Pada Kamus Besar Bahasa Indonesia, kata kinerja memiliki arti suatu hal yang ingin dicapai atau dapat juga dikatakan suatu prestasi yang ingin diperlihatkan. Menurut Hameed dkk (2004) dalam Endah et al. (2015:23), kinerja dapat disebut sebagai sebuah metode dalam mengukur pencapaian perusahaan yang dapat membantu perusahaan dalam memperbaiki kinerjanya dimasa depan. Fahmi (2011:2) menyatakan kinerja keuangan merupakan analisis yang dilakukan guna melihat aktifitas keuangan dan aturan pelaksanaan keuangan telah dilaksanakan oleh perusahaan dengan baik dan benar.

\section{Model SCnP}

Penilaian kinerja keuangan bank syariah dapat dilakukan dengan model SCnP. Pada model ini penilaian dilakukan dengan cara menggabungkan indikator kepatuhan terhadap sistem syariah dan indikator profitabilitas untuk menilai kinerja keuangan secara konvensional. Model SCnP dihitung dengan menggunakan dua variabel yaitu sharia conformity dengan menggunakan rasio investasi syariah, pendapatan syariah, dan rasio bagi hasil dan profitabilitas dengan menggunakan rasio ROA, ROE dan profit margin (Anggareni dan Hakim, 2016).

\section{Sharia Conformity}

Sharia conformity bertujuan untuk menilai besarnya aktifitas yang telah dijalankan bank dalam kegiatan operasionalnya yang sudah sesuai dengan sesuai dengan sistem syariah. Dalam hal ini yang diukur adalah besarnya tingkat investasi syariah, tingkat pendapatan syariah, dan tingkat bagi hasil syariah yang dilakukan oleh bank syariah 
tersebut (Ratnaputri, 2013). Ratnaputri (2013) menerangkan sharia conformity dapat diukur dengan tiga variabel sebagai berikut:

1) Investasi syariah

Investasi syariah merupakan aktifitas penempatan dana pada satu aset atau lebih yang mana didalamnya tidak mengandung unsur perbuatan maysir, gharar, dan riba. Diukur dengan cara membandingkan investasi syariah terhadap investasi syariah dan non investasi syariah.

2) Pendapatan syariah

Merupakan pendapatan yang diperoleh bank dari pembiayaan telah yang disalurkan bank. Adapun pendapatan syariah dapat diukur dengan cara membandingkan pendapatan syariah terhadap pendapatan syariah ditambah dengna pendapatn non syariah.

3) Bagi hasil adalah membandingkan pembiayaan musyarakah dan mudharabah terhadap total pembiayaan.

\section{Profitability}

Salah satu yang menjadi indikator penting yang juga menjadi kekuatan perusahaan dalam jangka panjangnya yaitu dengan adanya pengembalian atas investasi modal (Subramanyam dan John, 2014:143). Kasmir (2016:196) mendefinisikan rasio profitabilitas sebagai berikut:

Rasio untuk menilai kemampuan perusahaan dalam mencari keuntungan. Rasio profitabilitas juga memberikan ukuran tingkat efektifitas manajemen suatu perusahaan. Hal ini ditunjukkan oleh laba yang dihasilkan dari penjualan dan pendapatan investasi. Intinya adalah penggunaan rasio ini menunjukkan efisiensi perusahaan.

Dalam SCnP model, pengukuran terhadap kinerja keuangan salah satunya diukur dengan profitability (profitabilitas). Ratnaputri (2013) menerangkan profitabilitas bank dapat diukur dengan tiga variabel sebagai berikut:

1) ROA, yaitu rasio yang mengukur sejauh mana aset perusahaan dapat menghasilkan laba. Diukur dengan cara membandingkan pendapatan bersih terhadap total aset.

2) ROE, yaitu rasio yang mengukur sejauh mana modal perusahaan dapat menghasilkan laba. Diukur dengan cara membandingkan pendapatan bersih terhadap modal investor.
3) Profit Margin, yaitu rasio untuk digunakan untuk melihat seberapa besar pendapatan riil yang diterima oleh perusahaan. Diukur dengan membandingkan pendapatan bersih terhadap total pendapatan.

\section{CAMEL}

Salah satu alat yang digunakan untuk mengukur tingkat kesehatan suatu bank adalah dengan menggunakan CAMEL yang bertujuan untuk mengevaluasi kinerja keuangan bank umum di Indonesia (Yulianto dan Wiwit, 2012). Ratnaputri (2013) menjelaskan bahwa CAMEL digunakan untuk menilai rasio finansial yang diukur dalam beberapa aspek. Aspek modal diukur dengan menerapkan CAR, aspek kualitas aset diukur dengan menerapkan RORA, aspek manajemen diukur dengan menerapkan NPM, aspek kapasitas penghasilan diukur dengan ROA), dan aspek likuiditas diukur dengan FDR.

\section{Capital (Permodalan)}

Aspek permodalan dihubungkan dengan kemampuan bank atas penyediaan modal kewajiban minimum yang telah ditetapkan (Isma, 2016). Rasio ini digunakan untuk melihat kemampuan bank dalam memenuhi dan mempertahankan kecukupan penyediaan modalnya. CAR dihitung dengan cara membandingkan modal terhadap total ATMR (Aktiva Tertimbang Menurut Resiko).

\section{Asset Quality}

Susilo (2000) dalam Murdiati dan Medi (2014:16) mengatakan, semua aktiva bank baik itu rupiah ataupun valuta asing yang digunakan dalam mendapatkan penghasilan sesuai dengan fungsinya masing-masing disebut dengan aktiva produktif. Asset quality diproksikan dengan menggunakan rasio RORA (Return On Risk Asset). Rasio ini menunjukkan rasio antara laba sebelum pajak terhadap aset-aset beresiko yang dihitung dengan cara membandingkan laba sebelum pajak dengan aktiva produktif.

\section{Management}

Aspek ketiga dari rasio CAMEL adalah manajemen. Kualitas manajemen dari suatu bank menunjukkan kemampuan dalam mengidentifikasi, 
mengawasi, mengontrol, dan mengukur resiko-resiko yang timbul dari kebijakan yang dijalankan sebagai strategi bisnis demi mencapai target yang telah ditetapkan.

Merkusiwati (2007) berpendapat bahwa pada aspek manajemen, penilaian tingkat kesehatan bank dapat dilakukan dengan menggunakan rasio Net Profit Margin (NPM). NPM dihitung dengan membandingkan laba bersih terhadap laba usaha.

\section{Earning}

Aspek keempat dari rasio CAMEL adalah aspek earning atau rentabilitas. Kemampuan bank dimasa saat ini dalam mendukung operasinya hingga masa akan datang serta kemampuan bank dalam meningkatkan laba dan mengukur tingkat efisiensi dan efektifitas manajemennya disebut dengan rentabilitas (Isma, 2016). Earning diukur dengan menggunakan dua rasio yaitu Return On Assets ( ROA) yang digunakan untuk mengukur kemampuan manajemen dalam memperoleh laba dari total aktiva yang dimiliki dengan membandingkan laba sebelum pajak terhadap total aset, dan BOPO yang digunakan untuk mengukur tingkat efisiensi kemampuan bank dalam melakukan kegiatan operasinya dengan membandingkan beban operasional terhadap pendapatan operasional (Yulianto dan Apit,2012).

\section{Liquidity}

Likuiditas menunjukkan sejauh mana bank mampu menyelesaikan kewajiban jangka pendeknya pada tepat waktu. Menurut Taswan (2006:364) likuiditas merupakan kemampuan bank dalam menyediakan dana guna memenuhi penarikan simpanan dan permintaan kredit serta kewajiban lainnya yang tengah jatuh tempo. Likuiditas dihitung dengan menggunakan rasio FDR (Financing to Deposit Ratio) dengan membandingkan total pembiayaan yang diberikan bank terhadap dana pihak ketiga.

Secara ringkas, berikut adalah kerangka pemikiran penelitian ini.

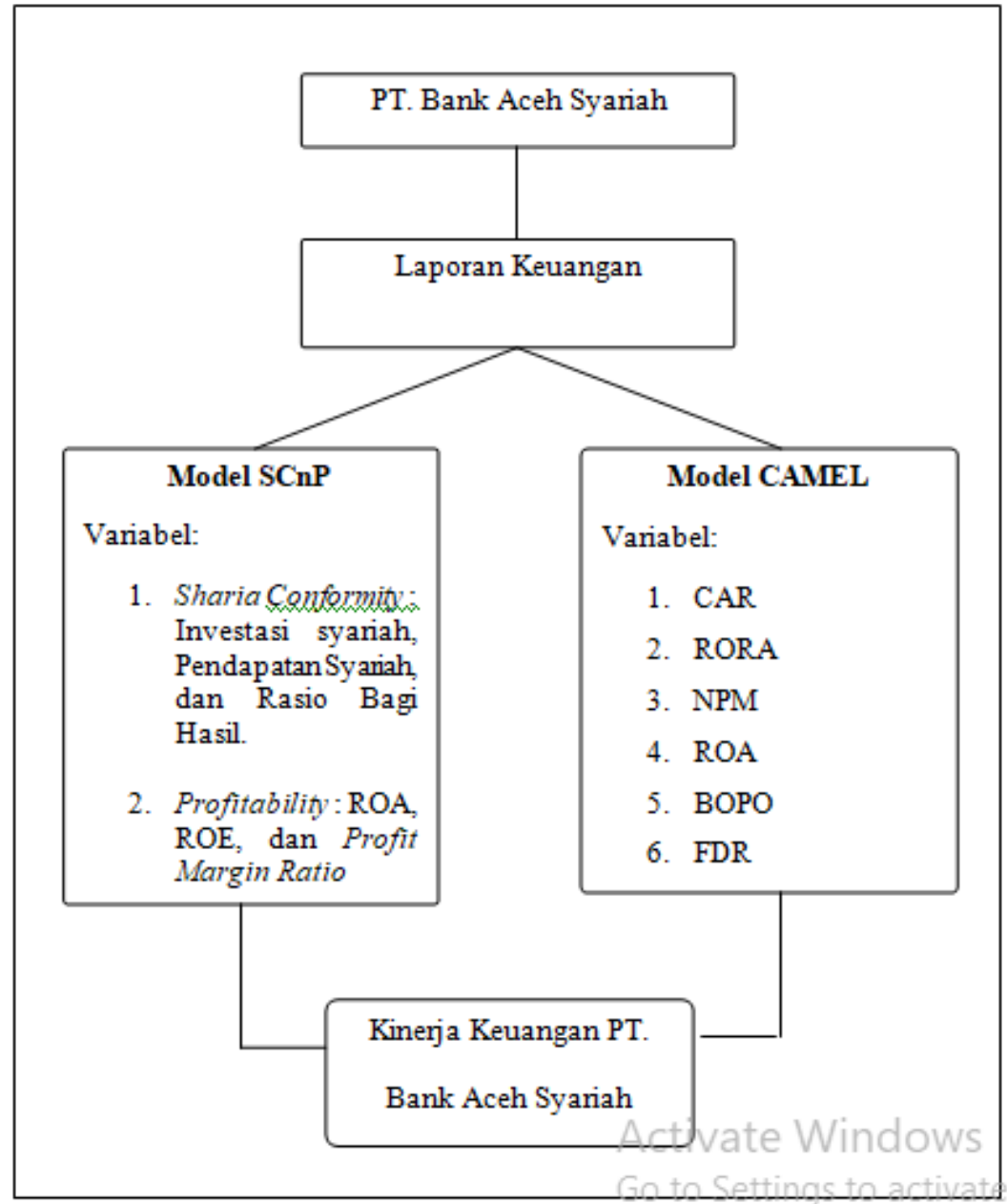

Gambar 2.1 Kerangka Pemikiran 


\section{Metodologi Penelitian}

\section{Desain Penelitian}

Tujuan dilakukan penelitian ini adalah untuk untuk menilai serta mengetahui tingkat kinerja keuangan pada PT. Bank Aceh Syariah menggunakan model SCnP untuk melihat sisi kepatuhan syariahnya, serta model CAMEL untuk melihat tingkat kesehatannya. Jenis investigasi yang digunakan dalam penelitian ini adalah korelasional.tingkat intervensi peneliti adalah minimal. Situasi studi yang diguakan pada penelitian ini tidak diatur. Sementara unit analisis pada penelitian ini yaitu PT. Bank Aceh Syariah, dan horizon waktu adalah cross sectional.

\section{Sumber dan Teknik Pengumpulan Data}

Sumber data pada penelitian ini adalah data sekunder yaitu berupa laporan keuangan bulanan yang dipublikasikan oleh PT. Bank Aceh Syariah selama 28 bulan terhitung sejak September 2016 hingga Desember 2018. Metode pengumpulan data yang digunakan yaitu dengan teknik pengumpulkan data kepustakaan/library research.

\section{Operasionalisasi Variabel}

\begin{tabular}{|c|c|c|c|}
\hline \multicolumn{4}{|c|}{ A. Sharia Conformity and Profitability (SCnP) } \\
\hline Nama Variabel & Variabel & Indikator & Skala \\
\hline \multirow{3}{*}{$\begin{array}{c}\text { Sharia } \\
\text { Conformity }\end{array}$} & Investasi Syariah & Investasi Syariah/Investasi Syariah + Investasi Nonsyariah & Rasio \\
\hline & Pendapatan Syariah & Pendapatan Syariah/Pendapatan Syariah + Pendapatan Nonsyariah & Rasio \\
\hline & Profit Sharing & Mudharabah + Musyarakah/ Total Pembiayaan & Rasio \\
\hline \multirow{3}{*}{ Profitability } & ROA & Laba Bersih/Total Aset & Rasio \\
\hline & ROE & Laba Bersih/TotalEkuitas & Rasio \\
\hline & Profit Margin & Laba Bersih/Total Pendapatan Operasional & Rasio \\
\hline \multicolumn{4}{|l|}{ B. CAMEL } \\
\hline Nama Variabel & Variabel & Indikator & Skala \\
\hline Capital & CAR & Modal Bank/Total ATMR & Rasio \\
\hline Asset Quality & RORA & Laba Sebelum Pajak/Risked Asset & Rasio \\
\hline Management & NPM & Laba Bersih/Laba Usaha & Rasio \\
\hline \multirow{2}{*}{ Earning } & ROA & Laba Sebelum Pajak/Total Aset & Rasio \\
\hline & BOPO & Beban Operasional/Pendapatan Operasional & Rasio \\
\hline Liquidity & FDR & Pembiayaan yang Diberikan/Dana Pihak Ketiga & Rasio \\
\hline
\end{tabular}

Sumber: Data diolah 2019

\section{Teknik Analisis Data}

\section{SCnP}

Penelitian ini menggunakan teknik deskriptif kuantitatif, dimana metode ini mengolah data rasio keuangan dari laporan keuangan bulanan bank lalu diinterpretasikan pada analisis SCnP. Penilaian berdasarkan model SCnP dilakukan dengan tahap berikut (Ratnaputri, 2013) :

1) Menghitung rasio variabel $\mathrm{SCnP}$

2) Menghitung rata-rata variabel sebagaimana formula berikut:

$$
\bar{X} S C=\frac{R 1+R 2+R 3}{3}
$$

$$
\bar{X} p=\frac{R 1+R 2+R 3}{3}
$$


Dimana :

SC : rata-rata rasio variabel Sharia Conformity

R1 : rasio islamic investment

$\mathrm{R} 2$ : rasio islamic income

R3 : rasio Profit sharing

P : rata-rata rasio variabel Profitability

$\mathrm{R} 1$ : rasio ROA

$\mathrm{R} 2$ : rasio $\mathrm{ROE}$

$\mathrm{R} 3$ : rasio profit margin

Rata-rata sharia conformity akan menjadi titik koordinat $\mathrm{X}$ dan rata-rata profitability akan menjadi titik pada koordinat $\mathrm{Y}$.

3) Menggambar grafik $\mathrm{SCnP}$

\section{CAMEL}

Pada model pengukuran CAMEL, teknik analisis penelitian ini mengacu pada penelitian yang dilakukan oleh Ratnaputri (2013) yaitu analisis kuantitatif deskriptif dimana penelitian ini akan membuat desksripsi dan gambaran secara sistematis mengenai fakta-fakta dari fenomena yang diselidiki. Pengukuran ini dihitung dengan menggunakan rasio dari data laporan keuangan publikasi bulanan bank.

Perhitungan dimulai dengan mencari nilai persentase dari masing-masing rasio. Setelah mendapatkan hasil nilai persentase, kemudian hasil tersebut digunakan untuk melihat predikat masingmasing dari variabel dengan ketentuan sebagai berikut:

1) Jika persentase hasil CAR dibawah $8 \%$, maka bank dalam kondisi tidak aman, karena modal yang dimiliki bank berpengaruh terhadap total aktiva yang dimilikinya.

2) Semakin tinggi nilai RORA yang dihasilkan, artinya semakin baik pula bank dalam mengelola aktiva produktifnya.

3) Jika nilai NPM mampu mencapai persentase diatas $81 \%$, maka hal tersebut dapat dikatakan baik karena bank mampu memperoleh laba terhadap adanya resiko.

4) Bank dikatakan memiliki performa baik jika nilai ROA mencapai standar $1,22 \%$, karena bank dapat menghasilkan laba bersih 1,22 dari jumlah aset 100 .

5) Jika hasil nilai BOPO kurang dari $93,52 \%$, maka dapat dikatakan bank tersebut dalam keadaan sehat.

6) Standar FDR yang ditentukan kurang dari 94,75\% menggambarkan keadaan bank yang baik. Semakin rendah nilai FDR, maka semakin baik.

\section{Hasil Penelitian dan Pembahasan}

\section{Analisis Kinerja Keuangan PT. Bank Aceh} Syariah menggunakan model SCnP

SCnP merupakan salah satu model yang digunakan dalam menilai kinerja keuangan perbankan, khususnya pada bank syariah. Penilaian dengan model $\mathrm{SCnP}$ menggabungkan dua orientasinya dalam melihat kinerja keuangan suatu perbankan, yaitu indikator orientasi kesesuaian terhadap sistem syariah dan profitabilitas. Pada caturwulan ketiga tahun 2016, PT. Bank Aceh Syariah secara resmi melakukan konversi dan mengubah sistem operasionalnya dari konvensional menjadi syariah. Pada akhir tahun 2016 kinerja bank syariah tersebar dalam satu sisi kuadran yaitu LLQ yang mengartikan bahwa tingkat kesesuaian syariah dan profitabilitas bank masih rendah. Bulan September 2016 yang merupakan langkah awal bank sebagai bank syariah hanya mampu berada pada posisi LLQ dikarenakan bank baru saja menjalankan kegiatan operasionalnya secara syariah. Kemudian diikuti oleh tiga bulan selanjutnya dimana bank juga masih berada pada posisi terendah dari seluruh kuadran yaitu pada posisi LLQ. Hal ini terjadi karena untuk profitabilitasnya bank belum mampu mencapai nilai ROA sebesar $1,22 \%$ seperti ketentuan yang berlaku.

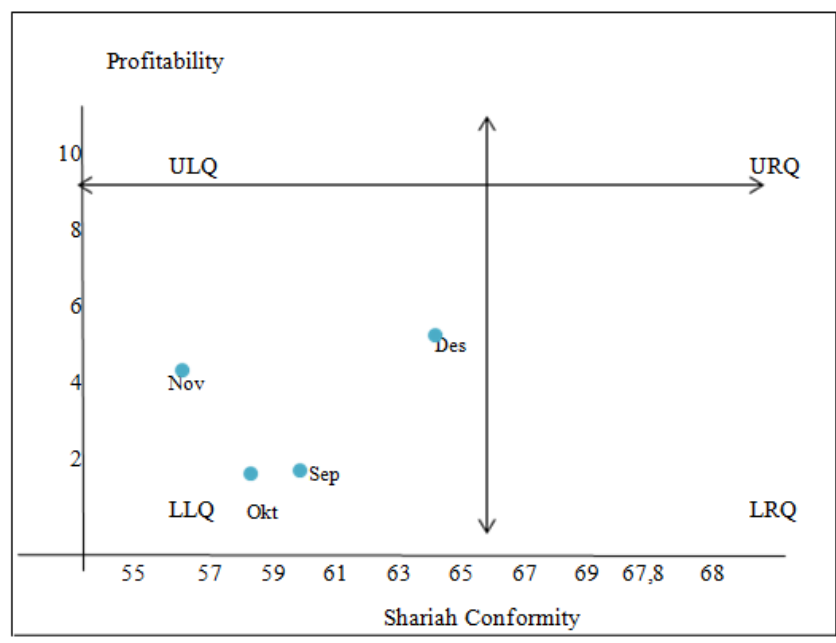

Gambar 4.1 Grafik model SCnP tahun 2016 
Pada tahun 2017, bank sudah memiliki tingkat profitabilitas yang tinggi, ditandai dengan persebaran titik pada posisi ULQ dan URQ. Hal ini mengartikan bank sudah memiliki tingkat kesesuaian syariah dan profitabilitas yang baik. Berbeda dengan hasil pada awal tahun 2017 yaitu pada bulan Januari bank berada pada posisi LRQ yang mengartikan tingkat profitabilitas bank masih rendah walau dari tingkat kesesuaian syariahnya cukup baik. Kemudian pada bulan Februari bank berada pada posisi LLQ seperti pada bulan Desember tahun sebelumnya. Hal ini menunjukkan bahwa tingkat kesesuaian syariah dan profitabilitas yang dimiliki oleh bank masih rendah.

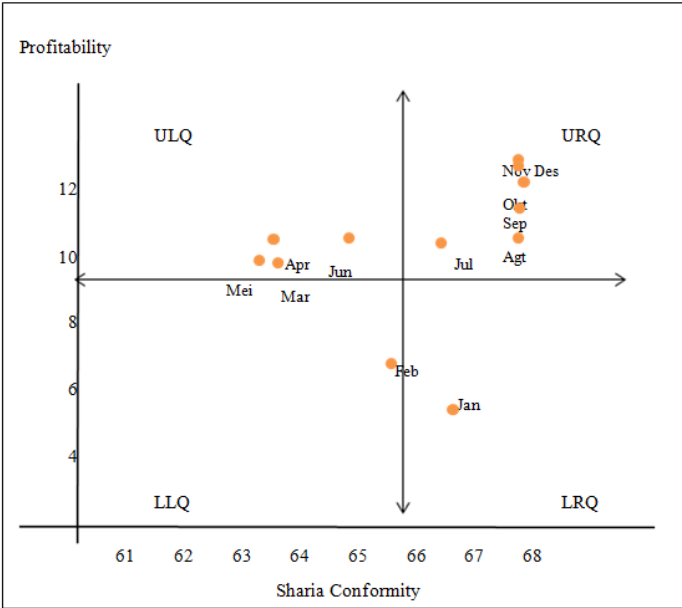

Gambar 4.2 Grafik model SCnP tahun 2017

Pada periode terakhir tahun penelitian yaitu tahun 2018, kinerja keuangan bank tersebar dalam dua posisi kuadran yang masing-masing pada sisi LRQ dan URQ. Bulan Januari 2018, bank sudah berada pada posisi URQ yang mengindikasikan pada bulan tersebut tingkat kesesuaian syariah dan profitabilitas bank sudah baik. Empat bulan selanjutnya terhitung dari bulan Februari hingga Mei 2018, posisi bank mulai bergerak menuju arah sisi kuadran LRQ, yang artinya pada bulan-bulan tersebut menunjukkan bank memiliki tingkat kesesuaian syariah yang baik tetapi tingkat profitabilitasnya menurun dari bulan sebelumnya. Kemudian pada bulan Juni hingga Desember 2018, bank mampu menunjukkan kemampuannya mencapai posisi terbaik kembali yaitu berada pada sisi URQ yang mengartikan bahwa bank memiliki tingkat kesesuaian syariah yang baik dan tingkat profitabilitas yang baik pula.

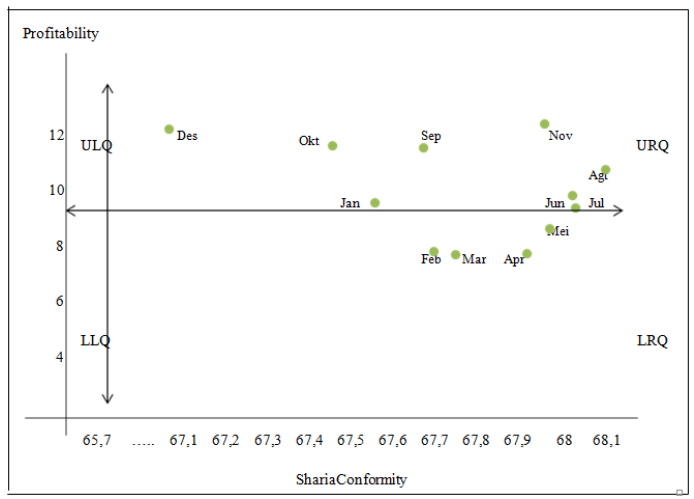

Gambar 4.3 Grafik model SCnP 2018

Selama tahun penelitian, kinerja PT. Bank Aceh Syariah yang diukur dengan SCnP model tersebar pada empat kuadran grafik SCnP. Pada Gambar 4.4 terlihat bahwa persebaran titik terbanyak terletak pada kuadran sisi URQ dan ULQ yang masing-masing kuadrannya didominasi dari analisis data tahun 2017 dan 2018. Sementara itu dua kuadran lainnya yaitu LLQ dan LRQ masingmasing terdapat hasil analisis data tahun 2016, 2017, dan 2018. Persebaran titik terbanyak terletak pada kuadran sisi URQ yang berarti bank sudah mampu memperoleh tingkat kesesuaian syariah dan profitabilitas yang baik. Tetapi ini kemudian berbalik pada tahun selanjutnya dimana kuadran posisi ULQ merupakan kuadran terbanyak kedua yang terdapat titik persebaran SCnP yang juga memiliki arti bahwa tingkat kesesuaian syariah bank sudah baik tetapi profitabilitasnya masih rendah. Hal ini menunjukkan bahwa bank mampu secara perlahan meningkatkan kinerja syariahnya dengan baik dengan tetap mempertahankan profitabilitas bank.

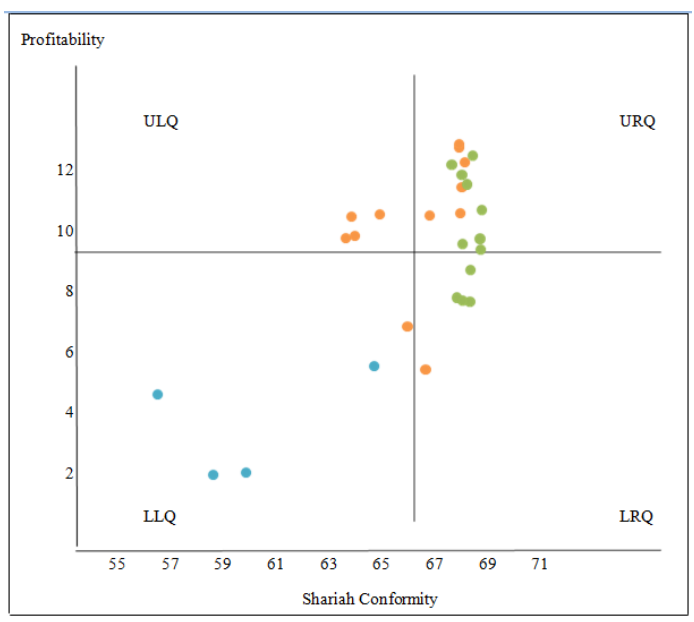

Gambar 4.4 Grafik model SCnP 2016-2018 
Analisis kinerja keuangan PT. Bank Aceh

Syariah menggunakan model CAMEL

Tabel 4.1

Nilai CAR, RORA, NPM, ROA, BOPO, dan FDR PT. Bank Aceh Syariah September 2016-Desember 2018

\begin{tabular}{|c|c|c|c|c|c|c|c|}
\hline Bulan & Tah un & CAR & RORA & NPM & ROA & ВОРО & FDR \\
\hline September & \multirow{4}{*}{2016} & 16,41 & 0,07 & 72,75 & 0,10 & 93,85 & 72,54 \\
\hline Oktober & & 15,72 & 0,11 & 78,43 & 0,15 & 95,20 & 71,25 \\
\hline November & & 16,19 & 0,33 & 77,53 & 0,45 & 88,37 & 69,05 \\
\hline Desember & & 16,16 & 0,52 & 113,9 & 0,72 & 91,15 & 88,94 \\
\hline Januari & \multirow{12}{*}{2017} & 17,21 & 0,11 & 85,31 & 0,15 & 83,58 & 89,55 \\
\hline Februari & & 17,55 & 0,26 & 80,27 & 0,38 & 78,35 & 91,09 \\
\hline Maret & & 17,31 & 0,57 & 78,53 & 0,77 & 69,69 & 85,57 \\
\hline April & & 16,52 & 0,76 & 78,27 & 1 & 70,29 & 75,17 \\
\hline Mei & & 16,12 & 0,75 & 79,07 & 1 & 73,83 & 64,07 \\
\hline Juni & & 13,59 & 0,90 & 80,08 & 1,20 & 75,43 & 66,70 \\
\hline Juli & & 13,73 & 1,01 & 80,25 & 1,37 & 77,11 & 67,17 \\
\hline Agustus & & 13,94 & 1,19 & 80,11 & 1,62 & 78,27 & 74,96 \\
\hline September & & 13,79 & 1,25 & 79,92 & 1,67 & 77,22 & 62,25 \\
\hline Oktober & & 14,07 & 1,48 & 79,74 & 1,98 & 76,45 & 64,35 \\
\hline November & & 14,48 & 1,66 & 80,26 & 2,22 & 76,19 & 64,62 \\
\hline Desember & & 13,76 & 1,74 & 81,30 & 2,34 & 77,99 & 73,06 \\
\hline Januari & \multirow{12}{*}{2018} & 15,87 & 0,22 & 77,10 & 0,30 & 66,16 & 72,92 \\
\hline Februari & & 15,93 & 0,32 & 77,51 & 0,44 & 74,30 & 72,12 \\
\hline Maret & & 15,18 & 0,45 & 77,91 & 0,62 & 76,75 & 72,04 \\
\hline April & & 15,34 & 0,56 & 76,61 & 0,76 & 77,83 & 71,42 \\
\hline Mei & & 15,26 & 0,74 & 76,63 & 0,93 & 76,64 & 64,74 \\
\hline Juni & & 14,57 & 0,86 & 76,64 & 1,10 & 76,81 & 62,94 \\
\hline Juli & & 15,19 & 1,08 & 76,54 & 1,38 & 76,78 & 65,52 \\
\hline Agustus & & 13,62 & 1,28 & 76,66 & 1,69 & 77,11 & 70,72 \\
\hline September & & 13,23 & 1,31 & 77,36 & 1,70 & 77,21 & 61,32 \\
\hline Oktober & & 13,55 & 1,55 & 77,38 & 1,92 & 78,01 & 62,75 \\
\hline November & & 13,91 & 1,74 & 77,68 & 2,18 & 77,88 & 64,41 \\
\hline Desember & & 14,11 & 1,81 & 78,26 & 2,32 & 79,50 & 75,96 \\
\hline
\end{tabular}

Sumber: Data diolah 2019

Besar rasio CAR didapatkan dengan membandingkan modal dan ATMR. ATMR didapatkan dengan mengalikan aktiva-aktiva beresiko sesuai dengan bobot resiko yang telah ditentukan. Pada tabel 4.10 terlihat bank mampu mencapai nilai CAR yang tinggi dan menghasilkan predikat yang sangat baik. Hal ini mengartikan bahwa bank sudah mampu dalam mengelola modalnya dengan sangat baik dan sesuai dengan ketentuan yang berlaku bank telah memenuhi kewajiban penyediaan modal minimum sebesar $8 \%$. Hal ini berbanding terbalik dengan hasil penelitian yang dilakukan oleh Ratnaputri dimana tidak satupun dari bank sampel yang mampu memenuhi ketentuan pengukuran CAR.

RORA diukur dengan membandingkan laba sebelum pajak dengan aset-aset beresiko. Laba sebelum pajak adalah laba yang dihasilkan bank selama periode tertentu sebelum dikurangi dengan pajak penghasilan bank. Pada tabel diatas dapat dilihat bahwa laba yang dihasilkan oleh bank bervariasi 
setiap bulannya. Selama periode tahun penelitian, bank mampu menujukkan kemampuannya dalam mengelola aktiva produktif, hal ini tergambar dari rasio yang dihasilkan bank terus mengalami peningkatan disetiap bulannya. Namun seperti rasio sebelumnya, pada setiap awal tahun periode akuntansi bank masih bergerak secara perlahan meningkatkan kemampuannya setelah pada periode tahun sebelumnya berakhir. Kemampuan tertinggi bank dalam mengelola aktiva produktifnya dalam periode bulanan yaitu pada Desember 2018. Hal ini terlihat jelas pada tabel diatas bahwa pada bulan Desember 2018, bank memiliki rasio RORA tertinggi selama periode tahun penelitian yaitu sebesar $1,81 \%$. Hal ini juga sejalan dengan penelitian Ratnaputri dimana bank sampel mampu mencapai kinerja yang baik selama tahun penelitian.

Pada tahun penelitian, rasio NPM yang dihasilkan bank sangat beragam. Untuk mencapai predikat terbaik dalam rasio NPM, bank harus mampu memenuhi kriteria lebih atau sama dengan $81 \%$. Namun, rata-rata rasio yang dapat dihasilkan bank untuk aspek manajemen ini hanya berada predikat cukup sehat yang artinya berada dibawah angka $81 \%$, kecuali pada Bulan Desember 2016, Januari 2017, dan Desember 2017. Hasil penelitian ini hampir memiliki kesamaan dengan penelitian yang dilakukan Ratnaputri walau selama tahun penelitian, rasio NPM yang dihasilkannya tidak mampu memenuhi ketentuan pengukuran untuk rasio NPM.

Rasio ROA yang dihasilkan oleh bank juga menunjukkan angka yang beragam. Pada tabel diatas dapat dilihat bahwa selama periode tahun penelitian rasio yang dihasilkan perusahaan terus meningkat, walau pada awal periode tahun penelitan bank belum mampu mendapatkan predikat terbaik dikarenakan hasil yang didapatkan tidak memenuhi kriteria ROA yang baik. Bank dapat dikatakan memiliki ROA yang baik apabila mampu memenuhi kriteria lebih dari atau samadengan $1,22 \%$. Sementara itu hasil penelitian menunjukkan bank baru dapat mampu memnuhi kriteria memiliki nilai ROA yang baik yaitu pada paruh kedua tahun periode akuntansi yang masingmasing pada tahun 2017 dan 2018 dengan mendapatkan predikat sehat. Hal ini dapat terjadi dikarenakan pada periode tersebut, bank mampu mencapai kinerja yang maksimal, dapat dibuktikan dengan laba yang diperoleh bank pada tiap paruh kedua tahun berjalan memiliki angka yang cukup tinggi jika dibandingkan paruh pertama masingmasing tahun. Hal ini juga mengindikasikan pada paruh kedua tiap tahun tersebut, bank dapat menghasilkan laba 1,22 dari jumlah aset 100. Hasil penelitian untuk rasio ROA ini berbeda dengan hasil penelitian yang telah dilakukan Ratnaputri bahwa terdapat dua bank sampel yang mampu memperoleh predikat baik pada penelitian tersebut.

Suatu bank dapat dikatakan memiliki rasio BOPO yang baik apabila berada dibawah $93,52 \%$. Pada tabel diatas terlihat bahwa rata-rata perolehan rasio BOPO selama periode penelitian memiliki predikat baik. Hal ini mengindikasikan bahwa bank mampu mengelola pendapatan yang diperoleh terhadap beban-beban yang terjadi selama periode masing-masing bulan. Kecuali pada dua bulan setelah masa konversi, bank masih memiliki predikat kurang sehat dan cukup sehat untuk kategori rasio BOPO. Hasil penelitian ini didukung dengan hasil penelitian yang dilakukan oleh NurAini (2013) yang menyatakan bahwa semakin rendah rasio BOPO akan meningkatkan pendapatan operasional bank yang kemudian akan menyebabkan perubahan laba yang besar.

Bank dikatakan memiliki rasio FDR yang baik apabila bank mampu mencapai kriteria kurang dari $94,75 \%$. Semakin kecil rasio yang dihasilkan maka semakin baik kinerja bank bila dilihat dari aspek likuiditasnya. Maka dalam hal ini, selama periode tahun penelitian bank mampu menunjukkan kemampuannya dalam mengelola likuiditas yang dimiliki. Hasil penelitian ini sejalan dengan penelitian oleh Ratnaputri dimana untuk rasio FDR, bank mampu memperoleh predikat yang baik, dimana pada penelitian tersebut bank Panin Syariah mampu memenuhi ketentuan pengukuran FDR.

\section{Perbedaan hasil penelitian dengan menggunakan model SCnP dan CAMEL}

Dari penelitian yang telah dilakukan dengan menggunakan model SCnP dan CAMEL yang dihitung berdasarkan indikator masing-masing terdapat beberapa perbedaan antara lain:

1) Perhitungan dengan menggunakan model $\mathrm{SCnP}$ dihitung dengan tiga indikator yaitu investasi syariah, pendapatan syariah, dan profit sharing. Sedangkan variabel profitability 
dihitung dengan tiga indikator yaitu ROA, ROE, dan profit margin. Selanjutnya persentase yang telah dihasilkan dari masing- masing indikator menjadi titik-titik koordinat pada grafik kuadran SCnP yang menunjukkan posisi kinerja yang telah dilakukan bank. Berdasarkan penelitian yang telah dilakukan diperoleh bahwa kinerja bank yang dihitung dengan model SCnP tersebar dalam empat kuadran yang memiliki ketentuan disetiap masing-masing sisi. Posisi terbaik dicapai oleh bank yaitu pada posisi URQ (Upper Right Quadrant) yang didominasi oleh bulanbulan di tahun 2017 dan 2018.

2) Perhitungan model CAMEL dengan menggunakan enam indikator yang masingmasing yaitu CAR, RORA, NPM, ROA, BOPO, dan FDR. Berdasarkan penelitian yang telah dilakukan, bank memiliki predikat yang beragam pada masing-masing indikator. Untuk rasio CAR, secara keseluruhan bank mampu mendapatkan predikat baik selama tahun penelitian. Untuk rasio RORA, bank terus menunjukkan peningkatan kinerja yang baik yang terlihat dari rasio yang dihasilkan terus mengalami peningkatan tiap bulannya. Kemudian rasio NPM, secara rata-rata bank menghasilkan predikat cukup baik selama tahun penelitian dikarenakan angka yang mampu dihasilkan masih berada dibawah ketentuan yang ditetapkan. Kemudian untuk rasio ROA, bank memperoleh predikat yang beragam yang secara rata-rata bank mencapai pada predikat cukup baik. Selanjutnta untuk rasio BOPO secara keseluruhan selama tahun penelitian bank memiliki predikat yang baik dan bank terus berupaya untuk konsisten dalam menjaga aspek pendapatannya. Terakhir untuk rasio FDR bank memiliki predikat yang baik selama periode tahun penelitian. Pada rasio ini bank mampu mencapai ketentuan yang telah ditetapkan sebelumnya dan terus konsisten mampu mencapainya sejak awal hingga akhir penelitian.

3) Dilihat dari hasil penelitian yang menggunakan dua model pengukuran tersebut diatas, masing-masing model memiliki hasil dan pencapaiannya sendiri. Untuk model SCnP yang digunakan untuk melihat kinerja bank dari sisi syariah, bank mampu mendapatkan hasil yang baik ditandai dengan keberadaan pada posisi yang terbaik dari empat posisi kuadran yang tersedia. Sementara untuk model CAMEL yang digunakan untuk melihat kinerja bank dari sisi keuangan atau finansial, bank juga mampu memperoleh hasil yang beragam dan menunjukkan kemampuan mendapatkan predikat yang baik pada beberapa indikator yang dihitung.

\section{Kesimpulan, Keterbatasan, dan Saran Kesimpulan}

Berdasarkan model SCnP, kinerja PT. Bank Aceh Syariah selama periode tahun penelitian tersebar pada empat sisi kuadran. Pada caturwulan ketiga tahun 2016 yang merupakan awal PT. Bank Aceh Syariah menjalankan aktifitasnya sebagai bank syariah menunjukkan kinerja yang masih berada pada posisi LLQ yang mengartikan tingkat kesesuaian syariah dan profitabilitas yang dimiliki bank masih lemah. Pada tahun 2018 bank berada pada posisi terbaik selama tahun penelitian yang rata-rata berada pada sisi URQ yang berarti bahwa pada tahun tersebut bank sudah mampu mencapai posisi terbaik yaitu dengan memiliki tingkat kesesuaian syariah dan profiatbilitas yang tinggi.

Berdasarkan model CAMEL yang dihitung dengan menggunakan 6 rasio yang mewakili aspek-aspek antara lain Capital, Asset Quality, Management, Earning, dan Liquidity memiliki hasil dan predikat yang beragam. Bank mampu menunjukkan kinerja yang baik pada rasio CAR, RORA, BOPO, dan FDR. Sementara pada rasio NPM dan ROA, bank belum mampu mencapai kriteria yang telah ditetapkan.

\section{Keterbatasan}

Keterbatasan pada penelitian ini adalah data yang digunakan berupa laporan keuangan publikasi bulanan bank setelah melakukan konversi kurang dari tiga tahun. Selain itu laporan keuangan bulanan yang digunakan juga laporan keuangan unaudited (tidak diaudit) sehingga informasi yang digunakan adalah informasi yang belum dinilai dan dilakukan pemeriksaan oleh auditor.

\section{Saran}

Dari penelitian yang dilakukan serta hasil 
penelitian yang telah diperoleh, maka peneliti ingin memberikan beberapa saran sebagai berikut.

1) PT. Bank Aceh Syariah sebaiknya banyak melakukan pembiayaan pada jenis pembiayaan produktif. Disamping dapat meningkatkan kesejahteraan masyarakat dengan membantu usaha-usaha yang dilakukan, juga dapat meningkatkan pendapatan bank dari pembiayanpembiayaan yang diberikan jika dibandingkan apabila pembiayaan tersebut bersifat konsumtif.

2) PT. Bank Aceh Syariah diharapkan dapat menggunakan model SCnP untuk mengukur tingkat kesesuaian syariah yang telah dijalankan di bank, mengingat PT. Bank Aceh Syariah sudah menjalankan aktifitasnya secara syariah, maka diperlukan alat untuk mengukur tingkat kesesuaian syariah yang telah dijalankan bank.

3) Bagi peneliti selanjutnya diharapkan dapat menggunakan alat ukur kinerja keuangan yang lain seperti maqasid indeks yang lebih banyak melihat sisi kinerja sebuah bank untuk penilaian secara syariahnya. Juga dapat menggunakan data berupa laporan keuangan tahunan PT. Bank Aceh Syariah setelah konversi sehingga informasi yang dihasilkan dapat menjadi referensi bank dan pihak pemakai laporan keuangan lainnya.

\section{Daftar Pustaka}

Anggraeni Prasetyowati, Lia., \& Lukman Hakim Handoko. 2016. Pengukuran Kinerja Bank Umum Syariah dengan Maqasid Index dan Sharia Conformity and Profitability (SCnP). Jurnal Akuntansi dan Keuangan Islam, 4:107-129.

Endah Retno Meilani, Sayekti., Dita Andraeny, \& Amin Rahmayati. 2015. Analisis Kinerja Perbankan Syariah di Indonesia dengan Menggunakan Pendekatan Islamicity Indices. Syariah Paper Accounting FEB UMS. 22-37.

Fahmi, Irham. 2011. Analisis Kinerja Keuangan. Bandung: Alfabeta.

Farlian, Talbani., \& Nuraidar. 2017. Meretas Reaksi Jalan Panjang Bank Aceh Konversi Syariah. Jurnal Perspektif Ekonomi Darussalam. Vol. 3,
No. 1.

Fitriani, Dewi. 2018. Perbandingan Kinerja Keuangan Syariah Antara Sharia Conformity and Profitability (SCnP) dan Sharia Maqasid Index (SMI) pada Bank Umum Syariah di Indonesia Periode 2011-2016. Skripsi. Jakarta: Universitas Islam Negeri Syarif Hidayatullah.

Isma Rokhaeni, Tri. 2016. Analisis Tingkat Kesehatan Bank Syariah dengan Menggunakan Metode CAMELS pada PT. Bank Syariah Mandiri Tahun 2010-2014. Tugas Akhir Dipublikasikan. Semarang: Fakultas Ekonomi dan Bisnis Islam Universitas Islam Negeri Walisongo.

Kasmir. 2016. Analisis Laporan Keuangan. Jakarta: PT. Raja Grafindo Persada.

Kbbi.kemdikbud.go.id.

Merkusiwati. 2007. Evaluasi Pengaruh CAMEL terhadap Kinerja Perusahaan. Bulletin Studi Ekonomi.

Nurdin, Ridwan. 2010. Akad-Akad Pada Perbankan Syariah di Indonesia (Sejarah, Konsep dan Perkembangannya). Banda Aceh: Yayasan PeNA.

Ratnaputri, Widya. 2013. The Analysis of Islamic Bank Financial Performance by Using CAMEL and Sharia Conformity and Profitability (SCnP). Jurnal Dinamika Manjemen, 4:215-226.

Republik Indonesia. Surat Keputusan Direktur Bank Indonesia Nomor 30/11/KEP/DIR Tanggal 30 April 1997 Tentang Tatacara Penilaian Tingkat Kesehatan Bank Umum

Subramanyam, K.R., \& John J Wild. 2014. Analisis Laporan Keuangan. Jakarta: Salemba empat. Sutrisno. 2014. Pengukuran Kesehatan Bank Syariah dengan Sharia Complience and Performance. Jurnal Keuangan dan Perbankan, 21:133-143.

Umardhani, Dwi, \& Abraham Muchlish. 2016. Analisis Perbandingan Kinerja Keuangan Bank Syariah dan Bank Konvensional di Indonesia. Jurnal Manajemen dan Pemasaran Jasa, 9:129-130. 
Yaya, Rizal., Erlangga Martawireja, Aji., Abdurahim, Ahim. 2016. Akuntansi Perbankan Syariah: Teori dan Praktik Kontemporer. Jakarta: Salemba Empat. Memprediksi Tingkat Kesehatan Bank yang Terdaftar Di Bursa Efek Indonesia Periode Tahun 2009-2011. Media Informasi \& Teknologi, 19: 35-49.

Yulianto, Agung, \& Wiwit Apit Sulistyowati. 2012. Analisis CAMELS dalam Memprediksi Tingkat Kesehatan Bank yang Terdaftar di Bursa Efek Indonesia Periode Tahun 20092011. Media Ekonomi dan Teknologi Informasi, 19: 35-9. 